\title{
Reynsla stjórnenda félagsmiðstöðva og frístundaheimila á tímum samkomubanns vegna COVID-19 vorið 2020
}

\author{
Kolbrún P. Pálsdóttir, Ársæll Már Arnarsson og Steingerður Kristjánsdóttir \\ Abstract Um höfunda About the authors $>$ Heimildir
}

Í pessari grein er fjallað um hvaða áhrif samkomubann vegna COVID-19 hafði á starfsemi og pjónustu frístundaheimila og félagsmiðstöðva á Íslandi vorið 2020. Markmið rannsóknarinnar var að varpa ljósi á viðhorf og reynslu stjórnenda af áhrifum samkomubanns á frístundastarf. Rafræn könnun fór fram 27. apríl til 26. maí 2020. Könnunin var send á netföng stjórnenda í frístundastarfi á höfuðborgarsvæðinu og á netföng alls starfsfólks grunnskóla á landinu. Svör 117 stjórnenda í frístundastarfi bárust, par af voru stjórnendur frístundaheimila $(\mathrm{N}=69)$ og stjórnendur félagsmiðstöðva $(\mathrm{N}=48)$. Meirihluti svarenda starfaði á höfuðborgarsvæðinu. Niðurstöður sýndu að starfsumhverfi félagsmiðstöðva og frístundaheimila á pessu tímabili var umtalsvert ólíkt. Pannig lá starfsemi flestra félagsmiðstöðva niðri að verulegu leyti pegar stjórnendum var gert að loka vegna samkomubanns, á meðan flest frístundaheimili tóku á móti börnum allan pennan tíma. Verulega dró pó úr mætingu barna á frístundaheimili og var rík áhersla lögð á vinnu með fámennari hópa og sóttvarnahólf. Stjórnendur frístundastarfs lögðu sig fram um að sýna sveigjanleika og frumkvæði til að viðhalda starfsemi fyrir börn og ungmenni. Engu að síður vekur áhyggjur að erfiðar gekk að virkja börn af erlendum uppruna til pátttöku á tímum samkomubanns. Mikilvægt er að próa leiðir til að ná betur til ungmenna af erlendu bergi brotnu og ungmenna sem eru félagslega einangruð. Stjórnvöld verða að huga að leiðum til að stuðla að aðgengi barna og ungmenna að öflugu og vel skipulögðu frístundastarfi á tímum heimsfaraldurs. Veita parf stjórnendum og starfsfólki frístundastarfs aukinn faglegan og hagnýtan stuðning.

Efnisorð: Frístundaheimili, félagsmiðstöðvar, samkomubann, líðan barna og ungmenna, félagsleg einangrun

\section{Inngangur}

COVID-19 heimsfaraldurinn hefur haft umtalsverð áhrif á skólagöngu og líf um 1,6 milljarðs barna og ungmenna í 190 pjóðríkjum í öllum heimsálfum (United Nations, 2020). Mest hafa áhrifin verið á börn sem tilheyra lágstéttarhópum og standa höllum fæti, s.s. vegna fátæktar, fötlunar, pjóðernis eða félagslegrar stöðu. Rannsóknir benda eindregið til að pátttaka í skipulögðu frístundastarfi geti skipt sköpum og stutt verulega við proska, velferð og nám nemenda sem takast á við félagslegar áskoranir (Ruth Jörgensdóttir Rauterberg og Kolbrún P. Pálsdóttir, 2015). Í pessari grein verður fjallað um hvaða áhrif samkomubann vegna COVID-19 hafði á starfsemi og pjónustu frístundaheimila og félagsmiðstöðva á Íslandi.

Pann 30. janúar 2020 lýsti Alpjóðaheilbrigðismálastofnunin (World Health Organization - WHO, 2020) neyðarástandi á heimsvísu vegna COVID-19 - lungnasjúkdóms sem orsakast af SARS-Cov-2 vírusnum. Premur dögum áður hafði verið lýst yfir óvissustigi vegna COVID-19 hér á landi. Frá pví að fyrsta auglýsingin um takmarkanir á skólastarfi var gefin út 13. mars 2020 (Heilbrigðisráðuneytið, 
2020) hefur rekstur leik- og grunnskóla sætt ýmiss konar takmörkunum og samkomubann verið í gildi með einum eða öðrum hætti (Embætti landlæknis og almannavarnadeild ríkislögreglustjóra, e.d.). Grunnskólum var pó heimilt að halda úti skólastarfi á pessum tíma með pví skilyrði að starfsfólk gætti að eins metra nándarreglu pegar andlitsgrímu var ekki viðkomið. Á peim tíma sem gagnaöflun fyrir pessa rannsókn fór fram, vorið 2020, var einstaklingum fæddum árið 2004 eða fyrr var óheimilt að vera fleiri en 30 í hverju rými. Petta átti einnig við um frístundaheimili, félagsmiðstöðvar og ípróttastarf í grunnskólum (Embætti landlæknis og almannavarnadeild ríkislögreglustjóra, e.d.). Sóttvarnaaðgerðir hafa pannig haft mikil áhrif á líf íslenskra barna og pátttöku peirra í skóla- og frístundastarfi. Prátt fyrir að fagfólk hafi lagt sig í líma við að halda uppi sem öflugustu starfi er ljóst að pær kynslóðir skólabarna, sem vaxa úr grasi á pessum fordæmalausu tímum, hafa upplifað verulega skerðingu í námi, félagslífi og hreyfingu.

\section{Mikilvægi frístundastarfs}

Frístundaheimili og félagsmiðstöðvar gegna mikilvægu hlutverki í lífi íslenskra barna og ungmenna. Félagsmiðstöðvar hafa verið starfræktar af sveitarfélögum um árabil og eru ætlaðar ungmennum á aldrinum 10-15 ára. Markmið peirra er að mæta börnum og unglingum á jafningjagrundvelli með gagnkvæmri virðingu (Alfa Aradóttir, Eygló Rúnarsdóttir og Hulda Valdís Valdimarsdóttir, 2017). Flest sveitarfélög á landinu reka frístundaheimili sem ætluð eru 6-9 ára börnum. Pau ganga undir mörgum öðrum nöfnum, svo sem heilsdagsskóli, gæsla, dægradvöl, skólasel, frístundasel og frístund (Kolbrún P. Pálsdóttir og Steingerður Kristjánsdóttir, 2017). Starfsemi frístundaheimila á sér stoð í grunnskólalögum og árið 2017 gaf mennta- og menningarmálaráðuneyti út gæðaviðmið um starfsemi peirra (Stjórnarráð Íslands, 2018). Félagsmiðstöðvar hafa ekki slíkan lagaramma en á móti kemur að starfið byggir á áralangri hefð æskulýðsstarfs á Norðurlöndum par sem horft er til pess að virkja ungt fólk á jákvæðan máta á peirra eigin forsendum (Eygló Rúnarsdóttir og Alfa Aradóttir, 2017).

Fagfólk á vettvangi frítímans byggir fagmennsku sína á pekkingu á óformlegri menntun, mikilvægi hins félagslega í námi og á gagnvirkum tengslum við ungt fólk. Rannsóknir á tengslum formlegs og óformlegs náms sýna að nám og proski mótast af fjölbreyttri reynslu par sem hið formlega og óformlega skarast (Kolbrún P. Pálsdóttir, 2019; Kumpulainen og Mikkola, 2015). Á tímum heimsfaraldurs par sem samskipti við jafnaldra eru takmörkuð og félagsleg einangrun eykst, verður enn mikilvægara en áður að horfa til óformlegra aðferða til að styðja við nám og proska ungmenna.

\section{Áhrif COVID-19 á skóla- og frístundastarf}

Heimsfaraldur COVID-19 hefur haft áhrif á líf flestra einstaklinga óháð aldri, kyni og bjóðerni. Miklar kröfur eru gerðar til fagfólks í skóla- og frístundastarfi á pessum sérstöku tímum, meðal annars um að endurskipuleggja starfshætti og leitast við að tryggja samfellu í lífi barna og ungmenna. Nýleg norræn rannsókn á áhrifum heimsfaraldursins á leikskólabörn leiddi í ljós að óvissan vegna hans endurspeglaðist í orðum og athöfnum ungra barna. Byggt var á viðtölum við 79 leikskólakennara um hvernig faraldurinn hefði birst í daglegu starfi og samskiptum við börnin. Mörg börn upplifðu mikla óvissu og spurðu stöðugt spurninga um COVID-19. Sóttvarnaaðgerðir höfðu ýmis neikvæð áhrif, til að mynda söknuðu mörg barnanna vina sem ekki mættu í leikskólann og nándarregla gat haft áhrif á tengsl starfsfólks og barna. Niðurstaða rannsakenda var að faglegt innsæi og rétt hvatning fagfólks skipti miklu máli og gæti stutt við seiglu og velferð barna (Heikkilä, Furu, Hellman, Lillvist og Rantala, 2020).

Faraldurinn hefur skapað ákveðna mótsögn í frítíma skólabarna, par sem sóttvarnaaðgerðirnar hafa annars vegar dregið úr möguleikum peirra til að taka pátt í hvers kyns tómstundum, en á hinn bóginn aukið mjög tímann sem pau hafa aflögu. Pannig hefur pessi faraldur dregið fram meginspurningu tómstundafræðinnar: Hvað eru tómstundir? İ Orðasafni i tómstundafraði (Ágústa Porbergsdóttir, Eygló Rúnarsdóttir, Hulda Valdís Valdimarsdóttir og Jakob Frímann Porsteinsson, 2019) eru tómstundir 
skilgreindar sem „meðvituð athöfn í frítíma sem byggir á frjálsu vali einstaklingsins, skapar tækifæri til reynslu og hefur jákvæð áhrif á velferð og lífsgæði“. I ýmsum öðrum vísindagreinum sem fást við proska einstaklingsins er hins vegar einvörðungu litið á tómstundir sem pað sem einstaklingur tekur sér fyrir hendur pegar hann er ekki að stunda nám eða vinnu (Vanda Sigurgeirsdóttir, 2010). Reikna má með pví að pessi frítími hjá skólabörnum nái alla jafna yfir allt að sjö klukkustundir á virkum degi og ljóst að pað hvernig pessum tíma er ráðstafað getur haft veruleg áhrif á proska peirra. Á tíma heimsfaraldurs pegar börn og fjölskyldur peirra eyða mun meiri tíma saman inn á heimilum verður aðkallandi að skoða pær breytingar sem urðu á frístundastarfinu. Frítími skólabarna hefur aukist til muna, en á sama tíma er ástæða til að hafa verulegar áhyggjur af skertum möguleiki peirra til að taka pátt í skipulögðu tómstundastarfi (Ettekal og Agans, 2020).

COVID-19 faraldurinn er ógnvekjandi og sögulegur atburður, sem hafa mun víðtæk og viðvarandi áhrif á alla pá sem upplifðu hann. Ef hann er skoðaður út frá vistfræðilíkani Bronfenbrenners pá má segja að allir pættir í lífi skólabarna hafi komist í uppnám vegna breytinga á athöfnum daglegs lífs, truflunum í upplýsingaflæði og samskiptum, og afgerandi og skyndilegra breytinga á reglum (Bronfenbrenner og Morris, 2006). Skipulagt frístundastarf er mikilvægur vettvangur félagsmótunar og má gera ráð fyrir að takmarkanir á frístundastarfi geti haft áhrif á proska og velferð barna og ungmenna (Ettekal og Agans, 2020).

Í nýlegri kanadískri rannsókn voru áhrif COVID-19 faraldursins skoðuð á hreyfingu, leik, kyrrsetu, skjátíma og svefn skólabarna. Í stuttu máli kom í ljós að börn og unglingar hreyfðu sig minna en fyrir faraldurinn, léku sér minna úti, eyddu meiri tíma fyrir framan skjái og sváfu lengur (Moore o.fl., 2020). Almennt komu stúlkur og eldri börn verr út. Höfundarnir bentu pó á að nokkrir pættir virtust einnig styðja frekar við hreyfingu, útileiki og svefn, og draga jafnframt úr skjánotkun og óhóflegum svefni. Pannig höfðu pættir, eins og að eiga yngri foreldra og hvetjandi foreldra, eða búa í einbýli fremur en fjölbýli, fylgni við minni neikvæðar breytingar af völdum COVID-19.

Alpjóðleg könnun á áhrifum faraldurs á menntakerfið var unnin af OECD í mars 2020. Helstu áskoranir pess, að mati svarenda, var að tryggja rafræna kennsluhætti og að styðja við vellíðan nemenda (Reimers og Scheichler, 2020). Athygli vekur að prátt fyrir áherslur á líðan og velferð nemenda, minnist skýrsla OECD ekki á gildi hins óformlega náms eða frístundastarfs. Samkvæmt fyrrnefndri könnun má einnig greina ýmis jákvæð áhrif heimsfaraldurs. Til að mynda töldu margir svarenda að nemendur hefðu fengið aukin tækifæri til sjálfstæðra vinnubragða; að samstarf við foreldra hefði alla jafna eflst; og að faglegt sjálfstæði kennara hefði aukist (Reimers og Schleicher, 2020). Umbylting hefðbundins skólastarfs vegna heimsfaraldurs virðist pví hafa haft í för með sér möguleika á nýrri nálgun og uppbroti á pví vandabundna og kerfislæga.

Hér að ofan hefur verið fjallað um samkomubann og takmarkanir á skólahaldi af völdum heimsfaraldurs vorið 2020. Gerð hefur verið grein fyrir mikilvægi frístundastarfs fyrir börn og ungmenni og nýjar rannsóknir á áhrifum kórónuveirufaraldursins á skólastarf og á velferð barna kynntar. Markmið rannsóknarinnar var að varpa ljósi á viðhorf og reynslu stjórnenda frístundaheimila og félagsmiðstöðva á Íslandi af áhrifum samkomubanns á starfsemina.

\section{Аðferð}

Byggt var á gögnum úr rafrænni spurningakönnun sem fram fór 27. apríl til 26. maí 2020 á vegum Menntavísindastofnunar Háskóla Îslands og send var á netföng alls starfsfólks grunnskóla á landinu og á netföng um 200 stjórnenda í frístundastarfi á höfuðborgarsvæðinu. Markmið könnunarinnar var að afla upplýsinga um áhrif heimsfaraldurs á starfsemi grunnskóla og á frístundastarf um allt land. Beiðni um pátttöku var ítrekuð fjórum sinnum (30. apríl, 7. maí, 13. maí og 20. maí). Ítrekanir voru aðeins sendar á netföng peirra starfsmanna sem ekki höfðu pegar svarað könnuninni.

Allir pátttakendur voru beðnir um að svara sömu grundvallarspurningunum en að auki fengu peir einnig sértækar spurningar eftir pví hvaða starfsheiti peir höfðu hakað við. Fjallað er um niðurstöður 
er varða aðra faghópa, par á meðal grunnskólakennara og proskapjálfa, í öðrum greinum í pessu sérriti. Einnig má nálgast heildarniðurstöður í sérstöku appi á heimasíðu Menntavísindastofnunar (sjá Menntavísindastofnun, 2020). Í pessari grein er einungis byggt á svörum peirra 117 pátttakenda sem skilgreindu sig sem stjórnendur frístundastarfs; par af voru stjórnendur frístundaheimila 69 og stjórnendur félagsmiðstöðva 48. Flestir svarendur voru á höfuðborgarsvæðinu.

Könnunin var framkvæmd með Qualtrics-forritinu og var tölfræðiforritið R notað til að greina niðurstöður. Um er að ræða lýsandi tölfræði par sem svör eru greind og kynnt eftir pví hvort pátttakandi starfaði á frístundaheimili eða á félagsmiðstöð.

\section{Niðurstöður}

Gögnin sýna að samkomubannið hafði ólík áhrif á starfsemi frístundaheimila annars vegar og á starfsemi félagsmiðstöðva hins vegar. Рað hafði í för með sér verulega skerta starfsemi peirra síðarnefndu. Um 63\% stjórnenda peirra svöruðu að félagsmiðstöðin hefði verið alfarið lokuð í samkomubanni og um $28 \%$ sögðu að lokað hefði verið að hluta. Einungis fjórir stjórnendur svöruðu pví til að félagsmiðstöðin hefði tekið á móti börnum allan tímann sem samkomubann stóð. Annað var upp á teningnum pegar kom að frístundaheimilum, pví par svöruðu um 83\% stjórnenda að opið hefði verið meðan á samkomubanni stóð.

Um 71\% stjórnenda félagsmiðstöðva sögðust hafa skipulagt rafrænt starf til að ná til og virkja ungmennin. Spurt var um hvernig rafræna frístundastarfið var útfært. Hlutfall svarenda sem hafði nokkuð oft eða alltaf farið eftirfarandi leiðir í rafrænu frístundastarfi á félagsmiðstöðvum var:

- 93\% notkun samfélagsmiðla (Facebook, Messenger, Instagram eða Twitter)

- $\quad 48 \%$ myndsamtöl (svo sem í gegnum Google Meet, Skype, Zoom eða Teams)

- $21 \%$ samskipti með tölvupósti

Notkun á námsumsjónarkerfi, s.s. Google Classroom, til samskipta við unglinga sem sækja félagsmiðstöðina virðist ekki hafa verið almennt notað af starfsfólk félagsmiðstöðva. Einungis fimm af peim 27 (18\%) sem svöruðu spurningunni sögðust hafa notað námsumsjónarkerfi og pá eingöngu sjaldan.

Í ljós kom að stjórnendur félagsmiðstöðva töldu sig ná misvel til ólíkra hópa ungmenna gegnum rafræna starfið, sjá Töflu 1.

Tafla 1. Hvernig gekk að fá ungmenni til að taka pátt í rafrænu félagsmiðstöðvarstarfi?

\begin{tabular}{lccccc}
\hline & & & & & Veit ekki/ \\
& Mjög vel & Frekar vel & Frekar illa & Mjög illa & Á ekki við \\
\hline Ungmenni með annað móðurmál & $0,0 \%$ & $20,0 \%$ & $50,0 \%$ & $16,7 \%$ & $13,3 \%$ \\
& $\mathrm{~N}=0$ & $\mathrm{~N}=6$ & $\mathrm{~N}=15$ & $\mathrm{~N}=5$ & $\mathrm{~N}=4$ \\
& $13,3 \%$ & $43,3 \%$ & $26,7 \%$ & $3,3 \%$ & $13,3 \%$ \\
Unglensku & $\mathrm{N}=4$ & $\mathrm{~N}=13$ & $\mathrm{~N}=8$ & $\mathrm{~N}=1$ & $\mathrm{~N}=4$ \\
& $13,3 \%$ & $63,3 \%$ & $20,0 \%$ & $3,3 \%$ & \\
Öll ungmenni með námsörðugleika & $\mathrm{N}=4$ & $\mathrm{~N}=19$ & $\mathrm{~N}=6$ & $\mathrm{~N}=1$ & \\
\hline
\end{tabular}

Niðurstöður sýndu glöggt að mesta áskorunin, að mati svarenda, var að virkja ungmenni með annað móðurmál en íslensku til pátttöku í rafrænu frístundastarfi. Einnig töldu svarendur að ungmenni með námsörðugleika (s.s. ADHD, lesblindu) tækju sîður pátt í rafræna starfinu en ungmenni almennt. Í opinni spurningu voru pátttakendur beðnir að lýsa pví sem peim hefði pótt erfiðast á tímum samkomubanns. Meðal pess sem starfsfólk félagsmiðstöðva nefndi var að pað hefði verið erfiðast að purfa að loka, að missa tengslin við félagslega einangraða unglinga og ná ekki til peirra sem ekki væru að nýta samfélagsmiðla. Einn svaraði á pessa lund: „Erfiðast hefur verið að vita af börnum sem purfa mikla félagslega örvun einangrast mögulega meira." 
Pátttakendur voru spurðir hvort peir hefðu haft samband við félagslega einangruð börn á tímum samkomubannsins. Mynd 1 sýnir að um helmingur stjórnenda félagsmiðstöðva $(\mathrm{N}=19)$ svaraði pví játandi og taldi sig hafa haft frekar eða mjög mikið samband við félagslega einangruð börn. Stjórnendur frístundaheimila virðast síður hafa haft samband við félagslega einangruð börn, en af peim 58 sem svöruðu spurningunni höfðu einungis um 17\% svarenda $(\mathrm{N}=10)$ frekar eða mjög mikið samband við félagslega einangruð börn.

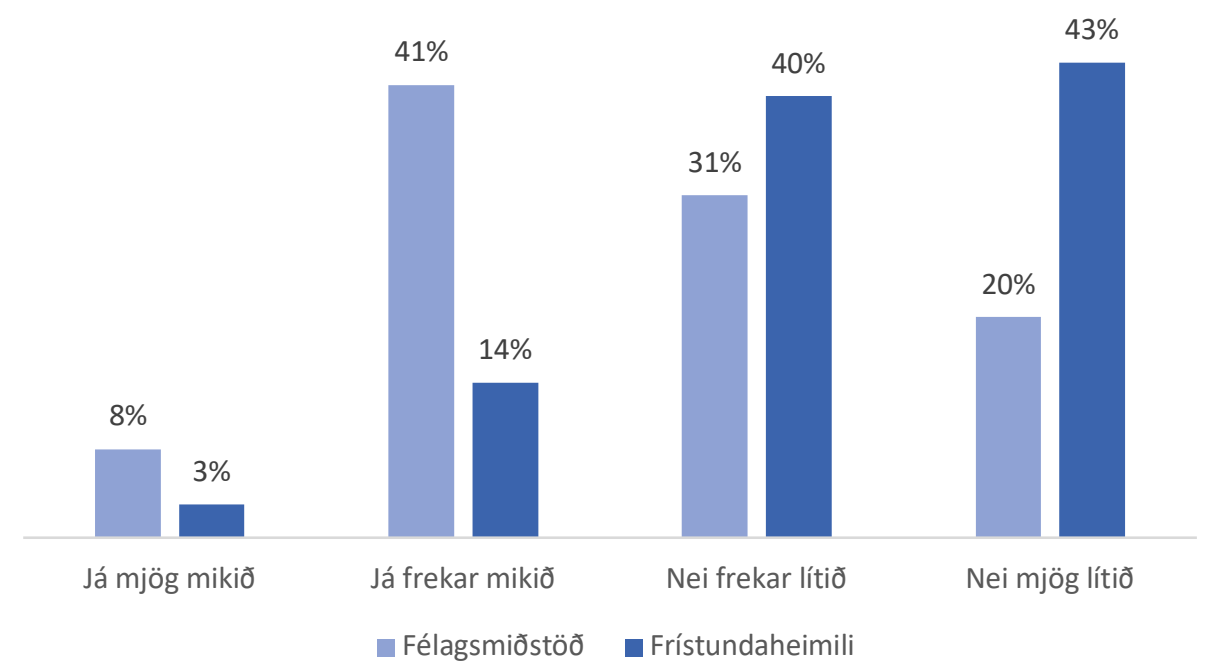

Mynd 1. Hafðir pú samband við félagslega einangruð börn á tímum samkomubanns?

Frístundaheimilunum var, sem fyrr segir, meira haldið opnum á tíma samkomubannsins. Mikill meirihluti svarenda í hópi stjórnenda peirra eða um 93\% ( $\mathrm{N}=55)$ sögðu að verkefni sín hefðu breyst að hluta eða mikið á tímabilinu. Meðal annars purftu stjórnendur að endurskipuleggja hópaskiptingu og tryggja sóttvarnahólf barna og starfsfólks. Sóttvarnayfirvöld lögðu ríka áherslu á að skólastofnanir viðhéldu sóttvarnahólfum og purfti frístundastarf einnig að taka mið af sömu hópaskiptingu. Í opnum svörum kom fram að hópaskiptingin hefði verið mikil áskorun, ekki síst í peim tilfellum par sem vinir lentu í mismunandi hópum. „Erfiðast hefur verið að horfa upp á krakka sem eiga sína bestu vini í öðrum bekkjum (eða vini sem eru heima í sóttkví) vera kvíðna yfir ástandinu og una sér ekki eins vel í frístundaheimilinu og venjulega," sagði einn pátttakandi. Рað vekur athygli að meirihluti stjórnenda frístundaheimila, eða um $66 \%(\mathrm{~N}=39)$, taldi sig vita til pess að börn ryfu sóttvarnahólf í frítímanum, p.e. léku sér við börn sem voru ekki úr sama bekk eða kennsluhópi.

Í opnum spurningum var spurt um áskoranir og tækifæri á tímum samkomubanns. Athygli vekur að nokkrir stjórnendur frístundaheimila ræddu sérstaklega um jákvæð áhrif pess að hafa fámennari hópa barna í daglegu starfi. Рað skapaði meiri rólegheit og tækifæri til að tengjast peim betur. Einn pátttakandi komst svo að orði: „Pegar börnin eru færri fær hvert og eitt peirra meira rými og meiri athygli frá starfsfólki. Рað hefur verið mikil og góð breyting fyrir börnin og sum peirra blómstrað í pessum breyttu aðstæðum. "Dæmi var um að pessar aðstæður hefðu haft pau áhrif að börn eignuðust nýja vini.

Mynd 2 sýnir mat stjórnenda á páttum sem lúta að eigin aðlögunarhæfni, innri hvatningu og stuðningi á tímum samkomubannsins. Pað er áhugavert hve margir stjórnenda töldu að peim hefði gengið vel að aðlaga sig að breyttum aðstæðum, eða 69\% stjórnenda félagsmiðstöðva (N=27) og 85\% stjórnenda frístundaheimila $(\mathrm{N}=45)$. Par sem flestar félagsmiðstöðvar lokuðu að hluta eða alveg á pessu tímabili er eðlilegt að stjórnendum peirra hafi ekki gengið vel að virkja ungmennin í breyttum aðstæðum. Svipað hlutfall svarenda, um helmingur, taldi sig hafa haft gaman af pví að glíma við pær áskoranir sem COVID-19 skapaði í frístundastarfi, eða 46\% stjórnenda félagsmiðstöðva $(\mathrm{N}=18)$ og $50 \%$ stjórnenda frístundaheimila $(\mathrm{N}=26)$. 




Mynd 2. Hlutfall svarenda sem eru sammála eða mjög sammála ofangreindum staðhæfingum.

Umhugsunarvert er að eingöngu rétt rúmur helmingur stjórnenda frístundaheimila ( $\mathrm{N}=23)$ og um $40 \%$ stjórnenda félagsmiðstöðva ( $\mathrm{N}=16)$ taldi sig hafa fengið ráðgjöf eða aðstoð við að endurskipuleggja frístundastarfið. Pegar spurt var hvað stjórnendur hefðu talið erfiðast á tímum samkomubannsins pá var ýmislegt nefnt, ekki síst fannst peim erfitt að hitta ekki samstarfsfólk sitt, áskorun að halda utan um dagskrána og halda starfsfólki við efnið. Vegna óvissu var erfitt að skipuleggja fram í tímann, líkt og kom fram í opnu svari eins pátttakanda: „Maður reyndi að setja upp vaktatöflu fyrir næstu viku á föstudegi, en síðan kom eitthvað annað fram á blaðamannafundi eða hjá skólastjórnendum um helgina og pá purfti maður að breyta hjá sér og skipuleggja allt upp á nýtt.“

Mynd 3 sýnir að töluverður munur er á foreldrasamstarfi milli frístundaheimila og félagsmiðstöðva. Upplifa stjórnendur frístundaheimila alla jafna mun meiri áhuga og stuðning frá foreldrum en stjórnendur félagsmiðstöðva.

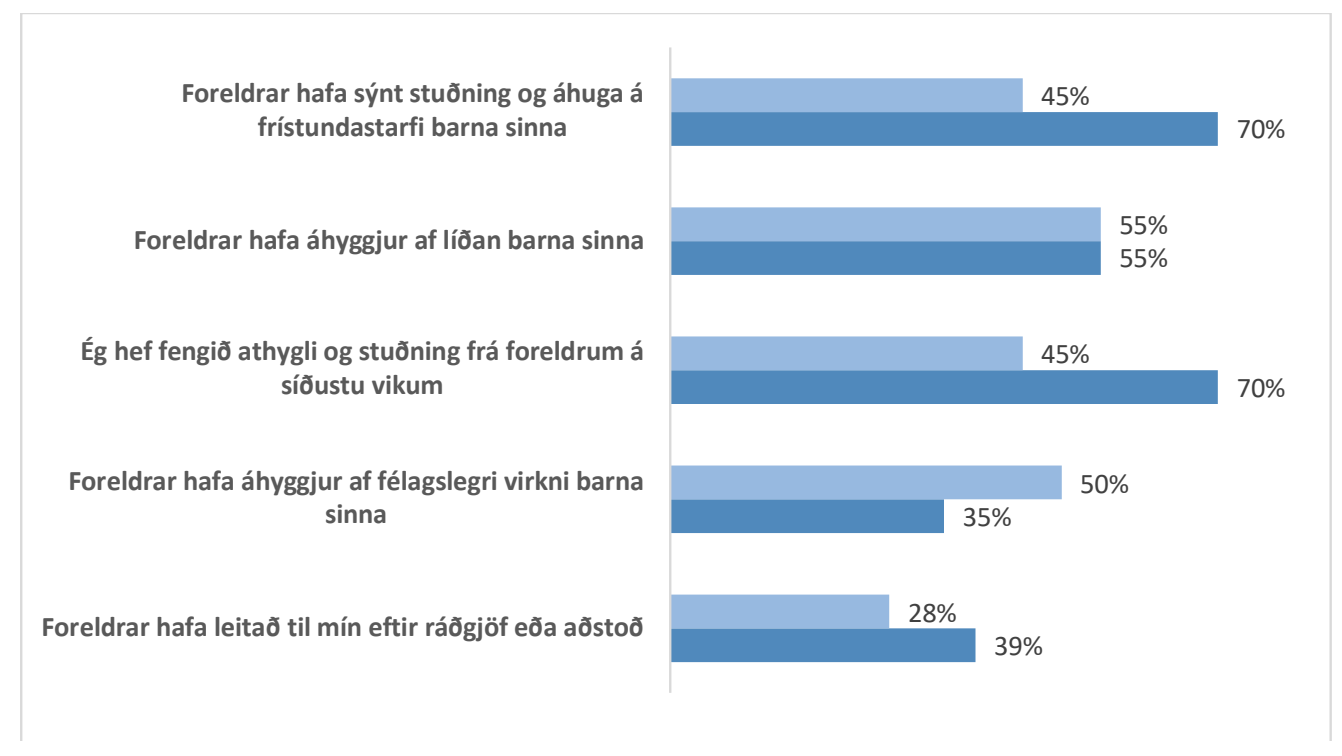

Mynd 3. Hlutfall svarenda sem eru sammála eða mjög sammála ofangreindum staðhæfingum um foreldra. 
Pótt báðir stjórnendahópar telji að foreldrar hafi áhyggjur af líðan barna sinna á tímum samkomubanns, pá töldu stjórnendur félagsmiðstöðva frekar að foreldrar unglinga hefðu áhyggjur af félagslegri virkni peirra. Stjórnendur frístundaheimila virðast í mun meiri samskiptum við foreldra en starfsfólk félagsmiðstöðva, sem kemur heim og saman við að félagsmiðstöðvar sinna ungmennum sem eru alla jafna mun sjálfstæðari en yngri skólabörn.

\section{Umræða og lokaorð}

Frístundastarf barna og ungmenna tók miklum breytingum í fyrstu bylgju COVID-19 á Íslandi vorið 2020. Flestar félagsmiðstöðvar urðu að loka en pó var nokkuð um að stjórnendur og starfsfólk skipulögðu rafrænt frístundastarf.

Í fyrsta lagi sýna niðurstöður rannsóknarinnar að starfsumhverfi félagsmiðstöðva og frístundaheimila er umtalsvert ólíkt. Meirihluti frístundaheimila var opinn á tímum samkomubanns, en daglegt starf tók mið af tilmælum yfirvalda um sóttvarnahólf og hópastærðir. Starfsemi félagsmiðstöðva lá niðri að verulegu leyti pegar stjórnendum var gert að loka vegna samkomubanns vorið 2020. Aðgengi unglinga að samfélagsmiðlum og sjálfstæði peirra skapaði nýja möguleika á að skipuleggja rafrænt frístundastarf, halda uppi tengslum og stuðla að félagslegri virkni unglinganna. Vert er að hafa í huga að eiginlegar tómstundir hverfast um jákvæða og uppbyggilega athöfn sem á sér stað í frítíma. Markmið frístundastarfs er að stuðla að velferð og proska ungmenna með markvissum hætti með aðferðafræði óformlegs náms. Gögnin sýna að innan frístundaheimila sköpuðust ný tækifæri vegna fámennari hópa barna og eru pessar niðurstöður sambærilegar við reynslu leikskólakennara á tímum samkomubanns (sjá Ingibjörg Ósk Sigurðardóttir og Svava Björg Mörk, 2020). Hugmyndafræði óformlegs náms, sem frístundastarf byggir á, skapar margvísleg tækifæri til að styðja við börn og ungmenni sem upplifa óvissu, áhyggjur og vanlíðan, líkt og í leikskólastarfi (Heikkilä o.fl., 2020).

Veruleg ástæða er til að hafa áhyggjur af skertu aðgengi unglinga að félagsmiðstöðvarstarfi á tímum COVID-19. Dví miður eru vísbendingar um að næstu misserin verði áfram reglulega takmarkanir á skóla- og frístundastarfi með tilheyrandi óvissu fyrir ungmenni. Rannsóknir hafa sýnt að pegar margir pættir í lífi ungmenna lenda í uppnámi getur tengslamyndun og stuðningur bæði jafnaldra og frístundaráðgjafa ráðið úrslitum (Moore o.fl., 2020). Sérstaklega parf að skoða betur hvernig megi ná til ungmenna af erlendu bergi brotnu og ungmenna sem eru félagslega einangruð. Pví miður staðfestir pessi rannsókn pað sem fyrri rannsóknir hafa einnig sýnt, nefnilega að samfélagsleg áföll hafa tilhneigingu til að afhjúpa pað félagslega ójafnræði sem ríkir í samfélaginu. Markvisst parf að próa leiðir til að virkja og ná til peirra barna og ungmenna sem höllum fæti standa. Náin samvinna milli starfsfólks skóla og starfsfólks í frístundastarfi er vænleg til að skila árangri.

Í öðru lagi sýna niðurstöður pessarar rannsóknar að stjórnendur frístundastarfs lögðu sig fram um að sýna sveigjanleika og frumkvæði til að viðhalda tengslum sínum við börn og ungmenni á tíma samkomubannsins. Engu að síður vekur pað áhyggjur að stjórnendur upplifðu miklar áskoranir við að ná til og virkja félagslega einangruð börn. Í nýrri grein Ettekal og Agans (2020) eru útlistaðar áskoranir og tækifæri sem liggja á sviði frítímans nú um stundir. Í fyrsta lagi parf frístundastarf að veita börnum áframhaldandi aðgengi að umhyggjusömum einstaklingi sem ekki er tengdur peim fjölskylduböndum. Slík samskipti geta tekið á sig ýmis form og verið bæði formleg og óformleg. Mestu máli skiptir að pau séu stöðug. Rannsóknir hafa sýnt að truflanir á slíkum samböndum geta verið skaðlegar, ekki síst ef bundinn er skyndilegur endir á slík sambönd án sampykkis barnsins (Grossman og Rhodes, 2002). Dví er til mikils að vinna að skoða sérstaklega hvernig megi ná enn betur til peirra ungmenna sem standa höllum fæti, ekki síst barna af erlendu bergi brotnu.

Í öllum alvarlegum kreppum felast tækifæri og gildir pað einnig um COVID-faraldurinn. Niðurstöður sýndu að stjórnendur frístundastarfs tókust alla jafna af jákvæðni og einurð á við pau óvæntu verkefni sem faraldurinn hafði í för með sér. Á sviði frítímans hefur til að mynda orðið gríðarleg aukning í notkun netlausna í starfi félagsmiðstöðva. Erlendar rannsóknir hafa einnig sýnt 
aukna virkni og samveru fjölskyldna, sem virðast leggja meira upp úr pví að gera hluti saman í frítímanum. Sameiginlegar tómstundir fjölskyldna geta hjálpað til við að draga úr ýmsum sálrænum fylgifiskum faraldursins, eins og kvíða og punglyndi (sjá Moore o.fl., 2020). Hér geta skipuleggjendur frístundastarfs lagt sitt af mörkum með pví að vinna að hugmyndabanka um frítíma fjölskyldunnar og miðla til foreldra. Hafa skal hugfast að frítími sem felur í sér niðurbrjótandi athafnir, sinnuleysi og samskiptaleysi er ekki uppbyggjandi og styður ekki við proska og velferð (Vanda Sigurgeirsdóttir, 2010).

Stjórnendur frístundastarfs töldu flestir ríka ástæðu til að hafa áhyggjur af líðan barna vegna takmarkana á félagslegum samskiptum og pví mikla uppbroti sem varð í samfélaginu. Pátttakendur upplifðu einnig áhyggjur foreldra af líðan barna sinna. Petta er í samræmi við könnun OECD sem sýndi að innan skólasamfélagsins töldu kennarar og skólastjórnendur að erfiðast væri að tryggja vellíðan nemenda, samhliða pví að skipuleggja nám og kennslu á rafrænan hátt (Reimers og Schleicher, 2020). Proski byggist meðal annars á að einstaklingar byggja ofan á og efla reynslu sína af veruleikanum. Nám barna verður pví fyrir miklum áhrifum af félagslegum breytingum og af pví sem gerist utan skóla (Bronfenbrenner og Morris, 2006; Moore o.fl., 2020). Miklu skiptir að skólasamfélagið í heild og allir aðilar sem starfa með börnum og ungu fólki leiti sameiginlegra leiða til að styðja við proska og velferð barna, ekki síst á tímum heimsfaraldurs.

Stjórnvöld verða pví að huga að leiðum til að stuðla að aðgengi barna og ungmenna að öflugu og vel skipulögðu frístundastarfi á tímum heimsfaraldurs. Veita parf stjórnendum og starfsfólki frístundastarfs faglegan og hagnýtan stuðning til að próa starfshætti í takt við breyttar aðstæður og parfir ungmenna. Skipulagt frístundastarf getur stutt verulega við að börn og ungmenni efli hæfni sína og styrkleika á tímum heimsfaraldurs (Ettekal og Agans, 2020). Valdefling og virk pátttaka ungmenna hefur verið einn af hornsteinum tómstundastarfs í mörg ár, en nú meira en nokkru sinni áður. Pví parf að nýta pessa leið til að hjálpa börnum að proska með sér hugsun, hegðun og félagsleg tengsl sem snúa að tilfinningastjórnun. Próa parf nýjar og skapandi leiðir til að virkja bæði ungmenni og fjölskyldur peirra meðan á faraldrinum stendur, og hér gegna stjórnendur frístundastarfs lykilhlutverki. Hafa skal í huga að áskoranir og breyttar aðstæður skapa einnig tækifæri fyrir sum börn að próa ný áhugamál og nýja hæfni.

Niðurstöðum ber að taka með fyrirvara vegna takmarkaðs fjölda pátttakenda sem störfuðu á vettvangi frístunda og mögulegrar skekkju sem pað getur valdið. Pó gefa niðurstöður mikilvæga innsýn í áhrif samkomubanns vorið 2020 á starfsemi frístundaheimila og félagsmiðstöðva frá sjónarhorni stjórnenda frístundastarfsins.

\section{Leisure-time centres and youth centres during meeting ban in Iceland spring 2020.}

The COVID-19 pandemic has had a significant impact on the schooling and lives of 1.6 billion children and young people in 190 nations on every continent. This article discusses the impact of the COVID-19 meeting ban on the activities and services of leisure-time centers and youth centers in Iceland. The aim of the study was to shed light on the attitudes and experiences of managers about the effects of the ban on daily activities. An electronic survey took place from 27 April to 26 May 2020. The survey was sent to e-mail addresses of managers in leisure activities in the capital area and to the e-mail addresses of all primary school staff in the country. This research explores only the responses from the 117 managers of leisure programs, the managers of leisure-time centers (i. frístundaheimili) $(\mathrm{N}=69)$ and the managers of youth centers (i. félagsmiðstöðvar) $(\mathrm{N}=48)$. Most participants worked in the capital area. Other articles in this special issue discuss findings relating to teachers in primary school and social pedagogues who work in schools. 
The results show a significantly different working environment of leisure centers, on the one hand-time centers and youth centers, on the other. The activities of most youth centers came to a significant halt when the management was forced to close due to the lockdown in spring 2020. The attendance of children at leisure-time centers decreased significantly and great emphasis was placed on smaller groups and quarantine compartments. Almost all managers of youth centers, 87\%, reported that the centers had been partially or completely closed during the lockdown. The situation was different when it came to leisure-time centers, as about $83 \%$ of managers answered that the leisure-time centers had been open during the lockdown. About $71 \%$ of youth center managers said they had organized online activities to reach and mobilize young people. The results clearly show that immigrant youth were least involved in electronic leisure activities and also that the participants believed young people with learning disabilities (e.g., ADHD, dyslexia) were less involved in online activities. It is noteworthy how many managers felt they had succeeded in adapting to changing circumstances. It is reasonable to estimate that since most youth centers were partially or completely closed, it was more challenging for the managers to mobilize the young people in these circumstances. It is noteworthy that only about half of the participants thought they had received advice or assistance in reorganizing their leisure activities. In open-ended questions participants were asked about the challenges and opportunities they had faced during the lockdown. It is interesting to note that some leisure center managers discussed in particular the positive effects of having smaller groups of children in their daily work. This created a calmer atmosphere and an opportunity to connect better with the children and the children also made new friends. The epidemiological authorities placed strong emphasis on the maintenance of quarantine cells by educational institutions, and leisure activities also had to comply with the same division into groups. The majority of the managers of leisure centers, about $66 \%$, thought they knew that children broke out of quarantine cells during their free time; that is, played with children who were not from the same class or teaching group. They found this very hard to control and had to tell the children that they might even not be able to play with their best friends.

The managers made efforts to show flexibility and initiative to maintain activities for children and young people during the lockdown. Nevertheless, it is worrying that only about a quarter of the participants answered positively to reaching out specifically to socially isolated children. It is important to develop ways to better reach immigrant youth and young people who are socially isolated. The government must consider ways to ensure that children and young people have access to dynamic and well-organized leisure activities during pandemics. The managers and leisure-time staff need to be given increased professional and practical support.

Key words: Leisure-time centres, Youth centres, Pandemic, the well-being of children and young people, social isolation

\section{Um höfunda}

Kolbrún P. Pálsdóttir (kolbrunp@hi.is) er dósent og forseti Menntavísindasviðs Háskóla Íslands. Hún lauk BA-prófi í heimspeki 1997, MA-grádu í menntunarfræðum 2001 og PhD-gráðu í menntunarfræðum frá Háskóla Íslands árið 2012. Rannsóknarsvið hennar eru meðal annars frístundaheimili, formleg og óformleg menntun, virk pátttaka og sjónarhorn barna. 
Ársæll Már Arnarsson (arsaell@hi.is) er prófessor í tómstunda- og félagsmálafræði við Menntavísindasvið Háskóla Íslands. Hann lauk BA-prófi í sálfræði 1993, MS-gráðu í heilbrigðisvísindum 1997 og PhD-gráđu í líf- og læknavísindum frá Háskóla Îslands árið 2009. Síðastliðinn áratug hafa rannsóknir hans aðallega snúið að heilsufari og líðan unglinga.

Steingerður Kristjánsdóttir (steingek@hi.is) er aðjúnkt í tómstunda- og félagsmálafræði við Menntavísindasvið Háskóla Îslands. Hún lauk B.Ed.-prófi frá Kennaraháskóla Íslands 1996 og MA-gráðu í mannauðsstjórnun frá Háskóla Îslands árið 2013. Steingerður starfaði sem verkefnisstjóri barnastarfs, fyrst hjá Íprótta- og tómstundaráđi Reykjavíkur og síðar Skóla- og frístundasviði á árunum 2002-2015. Rannsóknarsvið hennar eru meðal annars frístundaheimili, leikur barna og óformleg menntun.

\section{About the authors}

Kolbrún P. Pálsdóttir (kolbrunp@hi.is) is an associate professor and dean of the School of Education at the University of Iceland. She completed a BA degree in philosophy in 1997, an MA in education in 2001 and a PhD in education from the University of Iceland in 2012. Her research areas include leisure centers, formal and informal education, active participation and young people's perspectives.

Ársæll Már Arnarsson (arsaell@hi.is) is a professor of leisure studies at the University of Iceland School of Education. He completed a BA in psychology in 1993, an MSc in Health Sciences in 1997 and a PhD in Biomedical Sciences in 2009 from the University of Iceland. For the past decade his research has focused on the health and well-being of adolescents.

Steingerður Kristjánsdóttir (steingek@hi.is) is an adjunct teacher at the University of Iceland School of Education, Department of Leisure Studies and Social Pedagogy. She graduated with a B.Ed in teaching from Iceland College of Education in 1996, and completed an MA in Human resources management from the University of Iceland in 2013. Steingerður worked as a project manager for the Municipality of Reykjavik, mainly directing after-school programs and summer leisure programs for 6-12 yearold children. Her fields of research include: after-school programs, children's play and informal education.

\section{Heimildir}

Alfa Aradóttir, Eygló Rúnarsdóttir og Hulda Valdís Valdimarsdóttir. (2017). Frístundir og fagmennska. Rit um málefni fritímans. Reykjavík: Félag fagfólks í frítímapjónustu, Félag íprótta-, æskulýðs- og tómstundafulltrúa á Íslandi og Rannsóknarstofa í tómstundafræðum.

Ágústa Porbergsdóttir, Eygló Rúnarsdóttir, Hulda Valdís Valdimarsdóttir og Jakob Frímann Porsteinsson (ritstjórar). (2019). Orðasafn i tómstundafraði. Reykjavík: Orðanefnd í tómstundafræði.

Bronfenbrenner, U. og Morris, P. A. (2006). The bioecological model of human development. Í W. Damon og R. M. Lerner (ritstjórar), Handbook of child psychology: Vol. I. Theoretical models of human development (6. útgáfa, bls. 793-828). Hoboken, NJ: John Wiley \& Sons.

Embætti landlæknis og almannavarnadeild ríkislögreglustjóra. (e.d.). Covid.is. Sótt af http://www.covid.is

Ettekal, A. V. og Agans, J. P. (2020). Positive youth development through leisure: Confronting the COVID-19 pandemic. Journal of Youth Development, 15(2), 1-20. doi:10.5195/jyd.2020.962

Eygló Rúnarsdóttir og Alfa Aradóttir. (2017). Félagsmiðstöðvar barna og unglinga. Í Alfa Aradóttir, Eygló Rúnarsdóttir og Hulda V. Valdimarsdóttir (ritstjórar), Frístundir og fagmennska. Rit um málefni fritimans (bls. 109-121). Reykjavík: Félag fagfólks i fritímapjónustu, Félag iprótta-, askulýds- og tómstundafulltrúa á Íslandi og Rannsóknarstofa í tómstundafræðum. 
Grossman, J. B. og Rhodes, J. E. (2002). The test of time: Predictors and effects of duration in youth mentoring relationships. American Journal of Community Psychology, 30(2), 199-219. doi:10.1023/A:1014680827552

Heikkilä, M., Furu, A. C., Hellman, A., Lillvist, A. og Rantala, A. (2020). Barns deltagande i förskole- och daghemskontext under inledningen av coronavirusets utbrott i Finland och Sverige. Barn, 38(2), 13-28. doi:10.5324/barn.v38i2.3703

Heilbrigðisráðuneytið. (2020, 13. mars). Auglýsing um takmörkun á skólastarfi vegna farsóttar. Sótt af https:// www.stjornartidindi.is/Advert.aspx?RecordID=8c62ca54-58f8-4e3d-9202-070e59c34d04

Ingibjörg Ósk Sigurðardóttir og Svava Björg Mörk. (2020). Kófið og leikskólinn: „Petta var mögnuð „tilraun“ til að sjá gæðastarf verða til við skrítnar aðstæður“. Netla - Veftimarit um uppeldi og menntun. Sérrit 2020 - Menntakerfi og heimili á tímum COVID-19. Sótt af http://netla.hi.is/serrit/2020/menntakerfi_ heimili_covid19/08.pdf

Kolbrún P. Pálsdóttir. (2019). Connecting school and leisure-time centres. Children as brokers. Í S. Dockett, B. Perry og Jóhanna Einarsdóttir (ritstjórar). Listening to children's advice about starting school and school age care (bls. 99-115). London: Routledge, Taylor \& Francis Group.

Kolbrún P. Pálsdóttir og Steingerður Kristjánsdóttir. (2017). Frístundaheimili. Vettvangur barnanna. Í Alfa Aradóttir, Eygló Rúnarsdóttir og Hulda V. Valdimarsdóttir (ritstjórar), Frístundir og fagmennska. Rit um málefni fritimans (bls. 97-105). Reykjavík: Félag fagfólks í frítímapjónustu, Félag íprótta-, æskulýðs- og tómstundafulltrúa á Íslandi og Rannsóknarstofa í tómstundafræðum.

Kumpulainen, K. og Mikkola, A. (2015). Researching formal and informal learning: From dichotomies to a dialogic notion of learning. International Journal for Research on Extended Education, 3(2), 50-60. doi:10.3224/ ijree.v3i2.20889

Menntavísindastofnun. (2020). COVID-19 rannsóknir. Grunnskólinn og frístundastarf. Sótt af https://mennta visindastofnun.hi.is/is/rannsoknir/covid-19-rannsoknir

Moore, S. A., Faulkner, G., Rhodes, R. E., Brussoni, M., Chulak-Bozzer, T., Ferguson, L. J., Mitra, R., . . . Tremblay, M. S. (2020). Impact of the COVID-19 virus outbreak on movement and play behaviours of Canadian children and youth: A national survey. International Journal of Behavioral Nutrition and Physical Activity, 17(1), 85. doi:10.1186/s12966-020-00987-8

Reimers, F. og Schleicher, A. (2020). A framework to guide an education response to the COVID-19 pandemic of 2020. Sótt af https://www.hm.ee/sites/default/files/framework_guide_v1_002_harward.pdf

Ruth Jörgensdóttir Rauterberg og Kolbrún P. Pálsdóttir. (2015). Pátttökurannsókn á tómstundastarfi fyrir 10 til 12 ára börn: Leiðir til að skapa samvinnu- og námsferli í margbreytilegum barnahópi. Sérrit Netlu 2015 - Hlutverk og menntun proskapjálfa. Sótt af http://hdl.handle.net/1946/24507

Stjórnarráð Íslands. (2018). Grunnskólar. Frístundastarf í grunnskólum. Gæði frístundastarfs, viðmið á íslensku. Sótt af https://www.stjornarradid.is/verkefni/menntamal/grunnskolar/

United Nations. (2020). Policy brief: Education during COVID-19 and beyond. Sótt af https://www.un.org/ development/desa/dspd/wp-content/uploads/sites/22/2020/08/sg_policy_brief_covid-19_and_education_ august_2020.pdf

Vanda Sigurgeirsdóttir. (2010). Skilgreining á hugtakinu tómstundir. Rádstefnurit Netlu-Menntakvika 2010. Sótt af https://netla.hi.is/serrit/2010/menntakvika2010/025.pdf

World Health Organization - WHO. (2020). WHO director-general's statement on IHR emergency committee on novel coronavirus (2019-nCoV). Sótt af https://www.who.int/director-general/speeches/detail/ who-director-general-s-statement-on-ihr-emergency-committee-on-novel-coronavirus-(2019-ncov)

Kolbrún P. Pálsdóttir, Ársæll Már Arnarsson og Steingerður Kristjánsdóttir. (2020).

Reynsla stjórnenda félagsmiðstöðva og frístundaheimila á tímum samkomubanns vegna COVID-19 vorið 2020

Netla - Veftímarit um uppeldi og menntun: Sérrit 2020 - Menntakerfi og heimili á tímum COVID-19

Sótt af http://netla.hi.is/serrit/2020/menntakerfi_heimili_covid19/08.pdf

DOI: https://doi.org/10.24270/serritnetla.2020.15 